\title{
Preface
}

Twenty years ago only a handful of medievalists knew the name of Saint Hildegard of Bingen. But no sooner do contemporary tastes change than the past takes on new contours. Names from the margins of our historical awareness are rediscovered, illumined, shifted toward center. So it was that, with the help of a few art historians, the forgotten Georges de la Tour suddenly became a painter of the first rank. So it was that Felix Mendelssohn "discovered" Johann Sebastian Bach; Franz Pfeiffer discovered Meister Eckhart; and a sisterhood of nuns discovered Hildegard of Bingen.

Hildegard, whose personal fame reached from England to Byzantium during her lifetime (1098-1179), has always had admirers in her native Germany. But her reputation suffered eclipse not long after her death. Though celebrated throughout the Middle Ages as an apocalyptic prophet, she was all but forgotten as a versatile writer, composer, and scientist. Between the Reformation and the early twentieth century, an occasional author hailed her as a great woman, a great saint, or a great German. Flurries of publication marked the 750 th anniversary of her death in 1929 and the octocentennial in 1979. But her belated emergence as a major representative of twelfth-century civilization owes most to two factors: the feminist quest for a canon, and the critical schol- 
arship of the nuns at St. Hildegard's Abbey in Eibingen. Sister Maura Böckeler, who was attempting to revive and modernize Hildegard's distinctive theology, published a German translation of her most famous work, the Scivias, in 1928. Böckeler's Scivias, reprinted many times, became the first of a series; all of Hildegard's major works are now available in abridged German versions published by Otto Müller Verlag of Salzburg. In the meantime two other Eibingen nuns, Marianna Schrader and Adelgundis Führkötter, broke ground in 1956 with an important historical and paleographic study, establishing the long-contested authenticity of Hildegard's works beyond doubt. ${ }^{1}$ Together with Angela Carlevaris, Führkötter also published a critical edition of the Scivias for the series Corpus Christianorum: continuatio mediaevalis (Turnhout, 1978). But the rest of Hildegard's works, which are extensive, remain in limbo. Most of the printed texts are poor, and for the English-speaking reader, only brief excerpts are available in trustworthy versions.

Yet despite these problems, popular interest in Hildegard is burgeoning. Herbalists have begun to use her prescriptions and diets in their medical practice. A fashionable Catholic guru salutes her, generously but falsely, as the prophet of everything from ecological justice to global ecumenism. Novels and films about her life are under way, and illustrations from her works have been cast in ceramics and needlework for Judy Chicago's mammoth exhibition The Dinner Party. Her music in particular has received fresh attention, thanks to several fine recordings by English and Continental ensembles. Peter Dronke, the author of many perceptive essays on Hildegard, finds in her songs "some of the most unusual, subtle, and exciting poetry of the twelfth century." I I believe he is right, and I present this edition of Hildegard's lyrics to make this extraordinary body of work available both to the scholar and to the general reader.

1Marianna Schrader and Adelgundis Führkötter, Die Echtheit des Schrifttums der heiligen Hildegard von Bingen (Cologne and Graz, 1956).

2Peter Dronke, "Hildegard of Bingen as Poetess and Dramatist," in Poetic Individuality in the Middle Ages (Oxford, 1970): I5I. 
This volume contains a critical text of Hildegard's poetic cycle, the Symphonia armonie celestium revelationum [Symphony of the harmony of celestial revelations], together with two sets of facing-page translations, one in plain prose and the other in free verse. It is recommended that the general reader begin with the verse translations. The prose versions are offered partly as a corrective to my poetic license, but principally as an aid to the student who is trying to decipher Hildegard's rewarding but peculiar and often bewildering Latin. These prose versions are quoted in the examples throughout the introduction. The commentary at the end of the book includes manuscript information along with a discussion of each individual poem. For the benefit of musicologists and singers, it also provides cross-references to the German edition of Hildegard's music. ${ }^{3}$ All biblical citations refer to the Vulgate.

I thank the librarians at the Hessische Landesbibliothek in Wiesbaden and the Bibliotheek der St.-Pieters-\& $\alpha$-Paulusabdij in Dendermonde, Belgium, for their hospitality and for providing the manuscript photographs that appear on pages 52 and 53.1 am also grateful to the Württembergische Landesbibliothek in Stuttgart and the Österreichische Nationalbibliothek in Vienna. Oxford University Press has graciously permitted me to reprint the stanzas by Charles Williams which appear on p. 282 ; they are taken from Williams's play The House of the Octopus (London: Edinburgh House Press, 1945), as reprinted in his Collected Plays (London: Oxford University Press, 1963). Twelve of the poems in this volume have previously appeared, in slightly different form, as an appendix to my earlier study, Sister of Wisdom: St. Hildegard's Theology of the Feminine (Berkeley: University of California Press, 1987). Parts of the introduction have appeared in Arts or Sciences, a magazine published by Northwestern University (Fall r987).

This project would not have been possible without a travel

3Pudentiana Barth, M.-I. Ritscher, and Joseph Schmidt-Görg, eds., Hildegard von Bingen: Lieder (Salzburg, 1969). 
grant from Northwestern University, for which I am deeply grateful

As a literary scholar with no claim to expertise in music, I offer my observations on Hildegard's musical style with some trepidation. My particular thanks are due to the musicians and musicologists who have saved me from many errors and offered helpful suggestions: Theodore Karp, Barbara Lachman, William Mahrt, Therese Schroeder-Sheker, and Barbara Thornton. Marianne Richert Pfau Kindly agreed, when this project was near completion, to let me include her essay on Hildegard's music. My husband, Richard Kieckhefer, has read the manuscript, as always, with vigilance as well as tender loving care. I thank Lieven Van Acker for sharing his ideas on the thorny manuscript problems discussed in the Appendix. Finally, I am grateful to David Myers for nerving me to "write poems" instead of pallid academic facsimiles of Hildegard's Latin. The infelicities that remain are all my own.

\section{A Note on the Second Edition}

Ten years after the original publication of the Symphonia, I am pleased to offer the reader this second, revised edition. The bibliography and discography have been updated to include more recent editions, translations, studies, and recordings of Hildegard's works. In addition, I have thoroughly revised the prose translations for the benefit of readers and listeners who do not read Latin. Without departing from strict fidelity to Hildegard's texts, I now offer more fluent and elegant versions that do less violence to normal English syntax. Finally, in the case of a single poem (no. 29), I have changed my interpretation of the last three lines and modified my translation and comments accordingly. The other verse translations and all the Latin texts are unaltered.

BARBARA NEWMAN

Evanston, Illinois 
SYMPHONIA 
